\title{
Wzorcowanie wysokociśnieniowe gazomierzy - stanowisko z pętlą zamkniętą
}

\begin{abstract}
W artykule przedstawiono stosowane obecnie zasady badania i wzorcowania gazomierzy przy ciśnieniu roboczym. Poprawne wzorcowanie gazomierza jest kluczem do zapewnienia właściwej dokładności pomiaru. Omówiono zasady badania i weryfikacji gazomierzy w zależności od ciśnienia roboczego według norm europejskich EN 12480, EN 12261 oraz zaleceń OIML. Przybliżono również zagadnienie wzorcowania gazomierzy przy użyciu alternatywnych gazów - jako medium roboczego w instalacjach wysokociśnieniowych. Przedstawiono ogólny zarys stanowiska pomiarowego z zamkniętą pętlą wraz z opisem podstawowych elementów stanowiska.
\end{abstract}

Słowa kluczowe: gazomierze, gazomierze turbinowe, wzorcowanie, wzorcowanie wysokociśnieniowe, pętla zamknięta.

\section{Gas meters high pressure calibration - closed-loop test stand}

The article presents the rules currently applicable, for testing and calibration of gas meters at operating pressure. The proper calibration of gas meters is key to ensuring accuracy of the reading. The principles of testing and verification of meters, depending on the pressure according to European standards EN 12480, EN 12261 and OIML requirements are presented. Also the issue of the calibration of gas meters using alternative gases as the working medium in high-pressure closed-loops is presented. The overview of a measuring stand with a closed-loop and description of its basic elements are presented.

Key words: gas meters, turbine gas meters, calibration, high pressure calibration, closed-loop test stand.

\section{Wprowadzenie}

Obecnie brak jest w Polsce możliwości badania (przy ciśnieniu roboczym wymaganym przez właściwe specyfikacje techniczne) gazomierzy stosowanych w systemie dystrybucji i przesyłu gazu ziemnego, jak również gazomierzy wykorzystywanych do innych celów przy ciśnieniach roboczych powyżej 4 bar. Niemniej należy wspomnieć, że w ostatnim czasie ukończona została budowa laboratorium wzorcowania gazomierzy na wysokim ciśnieniu w tłoczni gazu w Hołowczycach (Gaz-System S.A.). Przy obecnym stanie prawnym gazomierze pracujące $\mathrm{w}$ sieciach gazowych wysokiego ciśnienia przed oddaniem do użytkowania powinny być poddane weryfikacji pierwotnej przy ciśnieniu bliskim ciśnieniu roboczemu, zgodnie z odpowiednią normą, lub być poddane legalizacji ponownej w warunkach ciśnienia atmosferycznego z użyciem powietrza, zgodnie z rozporządzeniem Ministra Gospodarki z dnia 28 grudnia 2007 r. w sprawie rodzajów przyrządów pomiarowych podlegających prawnej kontroli metrologicznej oraz zakresu tej kontroli [12]. Umożliwiają to stanowiska do wzorcowania gazomierzy przy wysokim ciśnieniu.

\section{Wzorcowanie przy niskim i wysokim ciśnieniu}

Poprawne wzorcowanie gazomierza jest kluczem do zapewnienia właściwej dokładności pomiaru. Wzorcowanie jest procesem porównywania jednego urządzenia pomiarowego z innym urządzeniem o znanej dokładności. Sposób ten sprawdza lub zapewnia korekcję dla badanego urządzenia na podstawie porównania $\mathrm{z}$ urządzeniem referencyjnym. Urządzenie referencyjne określane jest jako wzorzec. Wzorcowania gazomierzy przeznaczonych do pomiaru gazu ziemnego 
są zazwyczaj prowadzone na stanowiskach wykorzystujących jako medium robocze gaz ziemny. Stanowiska do wzorcowania gazomierzy z użyciem gazu ziemnego w szerokim zakresie ciśnień i temperatur są trudne oraz kosztowne w budowie i obsłudze, niemniej dają najlepszą niepewność pomiarów. Biorąc pod uwagę bardzo duże ilości gazu przesyłanego w systemie przesyłu, jak również dystrybucji gazu, szczególne znaczenie ma zapewnienie możliwie dokładnego rozliczenia ilości gazu mierzonego na wejściach i wyjściach systemu. Utrzymanie dokładności na właściwym poziomie wpływa na prawidłowe bilansowanie systemu. Równie istotne jest zapewnienie dokładnego rozliczania ilości gazu wprowadzanego do systemu przez dostawcę i odbieranego z systemu przez kupującego gaz. Bardzo ważne wobec tego jest prawidłowe określenie objętości gazu w warunkach roboczych, ponieważ ciśnienie robocze ma wpływ na charakterystykę gazomierza. Niezbędne jest więc wyznaczenie charakterystyki gazomierza w warunkach ciśnienia zbliżonego do przewidywanych warunków pracy tego urządzenia.

Wielu producentów gazomierzy turbinowych w momencie zakupu i dostawy zapewnia certyfikat wzorcowania powietrzem atmosferycznym, zgodnie z rozporządzeniem Ministra Gospodarki z dnia 28 grudnia 2007 r. Wzorcowanie powietrzem atmosferycznym jest proste $\mathrm{i}$ tanie $\mathrm{w}$ realizacji, ale ma zastosowanie tylko do zakresu przepływu przy bardzo niskich liczbach Reynoldsa. Liczba gazomierzy turbinowych wykorzystywanych w przemyśle gazu ziemnego pracujących w tak niskim zakresie liczby Reynoldsa jest bardzo ograniczona [8]. Ze względu na wagę wzorcowania dla zachowania dokładności pomiaru przepływu - wiele agencji regulacyjnych i organizacji ma zalecenia dotyczące dobrych praktyk wzorcowania gazomierzy turbinowych. Zalecenia Międzynarodowej Organizacji Metrologii Prawnej (OIML) nr R 137-1\&2:2012 [14] określają, by gazomierze turbinowe były wzorcowane w warunkach ich pracy lub zbliżonych. Zgodnie z OIML R 137-1\&2:2012 gazomierze powinny spełniać wymagania w deklarowanym zakresie ciśnienia. Błąd wskazania należy wyznaczyć co najmniej przy minimalnym i maksymalnym ciśnieniu roboczym, przy czym od reguły tej istnieje wyjątek: „Dla technologii, które okazały się niewrażliwe na ciśnienie, oraz gazomierzy miechowych badanie to nie jest stosowane" [3]. Zgodnie z punktem 13.1.3 zaleceń OIML R 137-1\&2:2012 badanie dokładności podczas weryfikacji pierwotnej należy przeprowadzić przy ciśnieniu jak najbardziej zbliżonym do roboczego. Badanie dokładności gazomierzy podczas badania typu WE powinno być wykonane przy najmniejszym i największym ciśnieniu roboczym. Jeśli jednostka notyfikowana potwierdzi, że ciśnienie nie ma wpływu na charakterystykę metrologiczną, badanie może być wykonane przy ciśnieniu atmosferycznym.
Zgodnie z zaleceniami stwierdzenie braku zależności od ciśnienia nie musi być zawsze poprzedzone stosownymi badaniami. Na przykład w badaniach gazomierzy rotorowych zgodnie z zaleceniami OIML w zakresie ciśnienia do 16 bar jednostka notyfikowana może przyjąć, że ciśnienie nie ma wpływu na charakterystykę, powołując się na normę zharmonizowaną dla gazomierzy rotorowych, która dopuszcza badanie takich gazomierzy przy ciśnieniu atmosferycznym [11].

Zgodnie z normą PN-EN 12480:2005+A1:2008 [11] weryfikację pierwotną gazomierzy rotorowych używanych do pomiaru objętości paliwa gazowego w zakresie maksymalnego ciśnienia roboczego (nadciśnienie w stosunku do ciśnienia atmosferycznego) do 16 bar włącznie należy przeprowadzać za pomocą powietrza lub gazu określonego w zakresie normy (tzn. pierwszej, drugiej lub trzeciej rodziny gazowej według EN 437) przy ciśnieniu atmosferycznym. Jeżeli odbiorca tego zażąda, weryfikacja pierwotna może być realizowana w warunkach bliskich rzeczywistym warunkom użytkowania gazomierza.

Według normy PN-EN 12261:2005+A1:2008 [10] podczas badania typu gazomierzy turbinowych przeznaczonych do użytkowania w zakresie ciśnień roboczych do 4 bar włącznie - błąd wskazań należy wyznaczyć w warunkach atmosferycznych, a w przypadku gazomierzy przeznaczonych do pracy w ciśnieniach powyżej 4 bar badania błędu wskazania należy wykonać przy co najmniej ciśnieniu minimalnym i maksymalnym podanym przez producenta. $\mathrm{W}$ przypadku maksymalnych ciśnień roboczych powyżej 50 bar badanie może być przeprowadzone przy ciśnieniu 50 bar [2]. Badania należy przeprowadzić przy użyciu powietrza lub gazu określonego w zakresie normy lub przy użyciu każdego innego gazu, jeżeli stosowanie tego gazu prowadzi do podobnych wyników pomiaru przy wartości liczby Reynoldsa mieszczącej się w zakresie $\pm 5 \%$ wartości tej liczby w przewidywanych warunkach pomiaru, przy ciśnieniu atmosferycznym ( \pm 100 mbar).

Weryfikację pierwotną takich gazomierzy należy wykonać takim samym medium jak w przypadku ciśnień do 4 bar, ale w zależności od ciśnienia roboczego, do jakiego gazomierz jest przeznaczony, wymagane jest wykonanie jednego lub więcej badań:

- Jeżeli $p_{\text {gmax }} \leq 4 p_{\text {gmin }}$, należy przeprowadzić jedno badanie przy ciśnieniu $p_{\text {test }}$. Gazomierze spełniające wymagania E.3.1, E.4.1 i E.5.1 uznaje się za spełniające te właściwości metrologiczne w zakresie ciśnień roboczych od $0,5 p_{\text {test }}$ do $2,0 p_{\text {test }}$, gdzie:

$p_{\text {gmax }}$ - górna wartość graniczna ciśnienia roboczego gazomierza,

$p_{\text {gmin }}$ - dolna wartość graniczna ciśnienia roboczego gazomierza, 
$p_{\text {test }}-$ ciśnienie pomiarowe $\mathrm{w}$ czasie indywidualnego badania gazomierza.

Wszystkie powyższe ciśnienia wyrażone są jako nadciśnienia.

- Jeżeli $p_{\text {gmax }}>4 p_{\text {gmin }}$ wymagane jest wykonanie dwóch badań przy $p_{\text {test min }}$ i $p_{\text {test max }}$. Gazomierze spełniające wymagania E.3.1, E.4.1 i E.5.1 uznaje się za spełniające te właściwości metrologiczne w zakresie ciśnień roboczych od $0,5 p_{\text {test min }}$ do $2,0 p_{\text {test max }}$, gdzie:

$p_{\text {test min }}, p_{\text {test } \max }-$ minimalne i maksymalne ciśnienia pomiarowe w czasie indywidualnego badania gazomierza, wyrażone jako nadciśnienia.

Dotychczasowe doświadczenia, które zostały opisane w pozycjach $[1,4,6]$, wskazują, że różnice pomiędzy charakterystykami gazomierzy turbinowych wzorcowanych powietrzem atmosferycznym a charakterystykami gazomierzy wzorcowanych przy ciśnieniu roboczym mogą przekraczać $1 \%$. Z tego względu zaleca się wzorcowanie gazomierzy pracujących przy ciśnieniu powyżej 4 bar przy ciśnieniu bliskim warunkom użytkowania gazomierza. Różnice mogą być zarówno dodatnie, jak i ujemne, w zależności od konstrukcji gazomierza, i mogą przyjmować wartości przekraczające 1\%. Wpływ ciśnienia na charakterystyki gazomierzy turbinowych jest pośredni, związany ze zmianami gęstości. Z uwagi na budowę gazomierzy turbinowych nie zaobserwowano samoistnego wpływu ciśnienia na ich charakterystyki [13].

Oddziaływanie ciśnienia i temperatury na charakterystykę gazomierzy rotorowych jest niewielkie. Zmiany charakterystyk spowodowane zmianami ciśnienia są zwykle poniżej 0,2\%. Według normy PN-EN 12480:2005+A1:2008 badanie wykonuje się powietrzem o gęstości $1,2 \mathrm{~kg} / \mathrm{m}^{3}$ lub gazem określonym w zakresie normy. Zgodnie z zakresem norma dotyczy gazomierzy o maksymalnym ciśnieniu roboczym mniejszym lub równym 16 bar. Na rynku dostępne są jednak gazomierze przeznaczone do wyższych ciśnień. Gazomierze rotorowe dwukadłubowe są mało wrażliwe na zmiany ciśnienia. Wzorcowanie przy wysokim ciśnieniu gazomierzy dwu- kadłubowych nie jest więc konieczne, natomiast w przypadku gazomierzy jednokadłubowych zaleca się uzyskanie deklaracji producenta o wpływie ciśnienia na charakterystyki, popartej wynikami badań, i dopiero na tej podstawie podjęcie decyzji co do konieczności wzorcowania wysokociśnieniowego. Badania powinny być wykonane przez laboratorium akredytowane [13].

Gazomierze ultradźwiękowe stosowane do rozliczeń powinny być wzorcowane przepływowo; w przypadku gazomierzy klasy 2 wykorzystywanych do bilansowania wzorcowanie przepływowe jest zalecane (patrz: PN ISO 17089). W odróżnieniu od wzorcowania przepływowego gazomierze ultradźwiękowe są poddawane przez producenta również wzorcowaniu bez przepływu (dry calibration), w czasie którego mierzona jest prędkość dźwięku dla każdej ścieżki akustycznej. Na działanie gazomierza może mieć wpływ obecność niektórych składników w gazie. W szczególności duża zawartość ditlenku węgla i wodoru w mieszaninie gazowej może wpływać na prace gazomierza ultradźwiękowego, a nawet ją uniemożliwić z uwagi na efekt absorpcji akustycznej. Producent powinien podawać przewidywane minimalne ciśnienie robocze, którego wartość będzie określała minimalne ciśnienie wzorcowania gazomierza [13].

Wzorcowanie w warunkach możliwie zbliżonych do warunków eksploatacyjnych ma sens, jeżeli gęstość i wraz z nią liczba Reynoldsa mogą wpływać na dokładność gazomierza. Głównym powodem prowadzenia wzorcowania przy wysokich ciśnieniach jest trudność ekstrapolacji wyników uzyskanych przy niskim ciśnieniu na wyższe ciśnienia, ponieważ może ona prowadzić do niedopuszczalnych błędów odczytu [5]. Dane pomiarowe uzyskane w badaniu przy niskim ciśnieniu nie zawierają wystarczających informacji, aby dokonać wiarygodnej prognozy dla krzywej błędów gazomierza pracującego przy wysokim ciśnieniu roboczym. Wyniki otrzymane przy niskim ciśnieniu są zazwyczaj silnie zakłócone przez tarcie łożysk i przepływ laminarno-turbulentny. Gdy strumienie są większe, gęstość i lepkość, wpływające na liczbę Reynoldsa, zaczynają odgrywać istotną rolę. Jedynie wyniki badań w warunkach zbliżonych do roboczych są wiarygodne.

\section{Wzorcowanie różnymi mediami}

Wzorcowanie gazomierzy z zastosowaniem alternatywnych gazów zamiast gazu ziemnego jest dopuszczalnym rozwiązaniem. Na przykład większość agencji regulacyjnych w świecie uznaje wzorcowanie wysokociśnieniowe gazomierzy turbinowych przy użyciu powietrza atmosferycznego jako ważną procedurę. Gaz ziemny i powietrze atmosferyczne nie są jedynymi nośnikami gazu do badania gazomierzy, w szczególności gazomierzy turbinowych. W za- mkniętych pętlach pomiarowych do wzorcowania gazomierzy z powodzeniem stosuje się ditlenek węgla, co potwierdzają pozycje [7] i [9]. Wzorcowanie gazomierzy turbinowych ditlenkiem węgla ma wiele zalet. Ditlenek węgla jest niepalny i znacznie bezpieczniejszy w użyciu niż gaz ziemny. Może być sprężony i krąży w pętli pomiarowej tak, aby wygenerować dużą wartość liczby Reynoldsa przepływu przy znacznie niższym ciśnieniu roboczym. Wyniki badań 
przeprowadzone dla gazomierzy turbinowych na stanowisku badawczym z użyciem ditlenku węgla są praktycznie identyczne z wynikami badań przy wysokim ciśnieniu z zastosowaniem gazu ziemnego. Popularność zyskują stanowiska pracujące $\mathrm{z}$ wykorzystaniem $\mathrm{CO}_{2}$. W przypadku zamkniętych pętli pomiarowych ze sprężonym powietrzem inwestycje są mniejsze niż dla obiegów otwartych. Inwestycje potrzebne na budowę stanowiska $\mathrm{z}$ pętlą zamkniętą z użyciem $\mathrm{CO}_{2}$ mogą być około 2 razy mniejsze niż z użyciem powietrza, ponieważ stabilizacja temperatury może być dokonywana w bardzo efektywny sposób przez wtrysk i odparowanie ciekłego $\mathrm{CO}_{2}[5]$.

Dla gazomierzy turbinowych wzorcowanych w innych warunkach niż warunki użytkowania, aby zapewnić podobieństwo dynamiczne przepływu w całym zakresie pomiarowym, zakres liczb Reynoldsa podczas wzorcowania i użytkowania gazomierza powinien być zbliżony. Podobieństwo dynamiczne (występujące przy takich samych wartościach $R e$ ) zapewnia podobieństwo profilu prędkości w poprzecznym przekroju strumienia gazu oddziałującego na turbinę. Gęstość gazu wpływa na energię strumienia gazu oddziałującego na turbinę. Im większa gęstość, tym charakterystyka gazomierza zbliża się coraz bardziej do idealnej. Doświadczenia potwierdzają, że przy większej gęstości poprawia się liniowość zależności między prędkością obrotową turbiny a strumieniem objętości, zwiększa się też zakresowość dzięki zmniejszeniu minimalnego strumienia. $Z$ uwagi na fakt, że gęstość zmienia się w przybliżeniu liniowo wraz z ciśnieniem, w normach i w literaturze jej wpływ rozpatruje się najczęściej pośrednio, jako wpływ ciśnienia [13].

Zgodnie ze standardem IGG [13] w tablicy 1 przedstawiono wyniki obliczeń ciśnienia, jakie należy zastosować podczas wzorcowania gazomierzy przeznaczonych do gazu ziemnego zaazotowanego i wysokometanowego, dla różnych gazów używanych do wzorcowania.
W przypadku wzorcowania gazomierzy za pomocą innych gazów laboratorium wykonujące wzorcowanie ma obowiązek wykazania spójności pomiarowej i równoważności warunków wzorcowania na podstawie innych dokumentów. Zapewnienie spójności pomiarowej jest sposobem zapewnienia, że dokładność wyników pomiarów z jednego układu pomiarowego lub wykonywanych za pomocą jednej metody pomiarowej może być powiązana w znany sposób (przeniesiona) z wynikami z innego układu lub metody [13].

Można stwierdzić, że gazomierz turbinowy jest urządzeniem, które zamienia energię kinetyczną przepływającego medium na ruch obrotowy turbiny. Prędkość obrotowa idealnego gazomierza turbinowego powinna być dokładnie proporcjonalna do objętościowego natężenia przepływu medium. Prędkość obrotowa wirnika turbiny jest w przybliżeniu proporcjonalna do strumienia objętości przepływającego medium. Jednak w zależności od konstrukcji i stanu technicznego gazomierza można zaobserwować odchylenie o różnym stopniu od prędkości obrotowej idealnego gazomierza turbinowego. Spadek ten jest spowodowany momentem opóźnienia wirnika. Dwa składniki, które tworzą ten moment, to siły tarcia mechanicznego i siły tarcia płynu. Stosunkowo niewielka liczba Reynoldsa $(R e<2000)$ wskazuje, że dominują siły lepkości i dlatego przepływ ma laminarny charakter. Stosunkowo duża liczba Reynoldsa $(R e>4000)$ powoduje przepływ turbulentny. Przepływ płynu jest w stanie przejściowym, gdy liczba Reynoldsa wynosi od 2000 do 4000 [7].

Równoważnik gazu ziemnego pod ciśnieniem, który daje taką samą liczbę Reynoldsa jak strumień gazu testowego w gazomierzu badanym, jest znany jako efektywne ciśnienie badawcze $P($ eff $)$. Ciśnienie efektywne gazu testowego można określić za pomocą zależności liczby Reynoldsa gazu testowego i liczby Reynoldsa gazu ziemnego. Efektywne ciśnienie gazu testowego zmienia się tylko nieznacznie $\mathrm{z}$ temperaturą pracy i ciśnienia. Na podstawie tych zależności można

Tablica 1. Wartości ciśnień wzorcowania w zależności od stosowanego gazu

\begin{tabular}{|l|c|c|}
\hline \multirow{4}{*}{ Rodzaj gazu w sieci } & Gęstość na stanowisku wzorcowania & $\begin{array}{c}\text { Ciśnienie wzorcowania } \\
{[\text { bar] }}\end{array}$ \\
\hline \multirow{4}{*}{ Gaz ziemny zaazotowany - ciśnienie robocze 50 bar } & Gaz ziemny zaazotowany & 50,0 \\
\cline { 2 - 3 } & Gaz ziemny wysokometanowy & 53,8 \\
\cline { 2 - 3 } & Powietrze & 49,9 \\
\cline { 2 - 3 } Gaz ziemny wysokometanowy - ciśnienie robocze 50 bar & Azot & 49,9 \\
\cline { 2 - 3 } & Gaz ziemny wysokometanowy & 25,8 \\
\cline { 2 - 3 } & Gaz ziemny zaazotowany & 46,6 \\
\cline { 2 - 3 } & Powietrze & 50,0 \\
\cline { 2 - 3 } & Azot & 46,5 \\
\hline
\end{tabular}


stwierdzić, że powietrze wywołuje podobną liczbę Reynoldsa do gazu ziemnego, natomiast korzystne byłoby zastąpienie gazu ziemnego w zamkniętej pętli testowej ditlenkiem węgla w celu otrzymania liczby Reynoldsa dwukrotnie wyższej przy tym samym ciśnieniu próbnym.

Wzorcowanie gazomierzy turbinowych z zastosowaniem ditlenku węgla niesie ze sobą kilka korzyści:

- ditlenek węgla jest niepalny - jest bezpieczniejszy w obsłudze niż gaz ziemny,

- niższe w stosunku do gazu ziemnego i powietrza ciśnienie robocze niezbędne do osiągnięcia wymaganej liczby Reynoldsa wymaga mniejszej kompresji,

- fakt, że stanowisko wzorcowania wykorzystujące ditlenek węgla może pracować przy niższym ciśnieniu, oznacza, że automatyczne urządzenia bezpieczeństwa mogą być łatwiej i mniej kosztownie wdrożone,

- ze względu na większą gęstość ditlenku węgla nie ma konieczności korekty gęstości, aby poprawić dokładność wzorcowania,

- osiągnięcie punktu potrójnego ditlenku węgla następuje znacznie bliżej do warunków otoczenia niż w przypadku większości gazów, co umożliwia kontrolowaną regulację temperatury przepływającego gazu w pętli pomiarowej poprzez bezpośrednie wtryskiwanie ditlenku węgla w fazie ciekłej.
Z powodu tych właściwości ditlenku węgla i po zastosowaniu sposobu regulacji temperatury opatentowanego przez Terasen (patent U.S., styczeń 2007) temperatura przepływającego gazu w pętli pomiarowej gazomierza może być sterowana w granicach $\pm 1^{\circ} \mathrm{C}$ pomiędzy $5^{\circ} \mathrm{C}$ i $40^{\circ} \mathrm{C}$. Możliwość ta jest wyjątkowa wśród dużych stanowisk wzorcowania gazomierzy, jako że tylko niektóre mają zmienną temperaturę roboczą [7].

Jak przedstawiono powyżej, podstawy do zastosowania innego medium niż gaz ziemny daje teoria podobieństwa dynamicznego (jest spełniona, kiedy skale podobieństw różnych wielkości charakterystycznych pozostają w ściśle określonych zależnościach, np. liczba Reynoldsa dla przepływów, zależności te uzyskuje się na drodze analizy wymiarowej) Teoria ta mówi, że niezmiennym modułem bezwymiarowym, który musi być zachowany, jest liczba Reynoldsa $(R e)$, a pozostałe współczynniki zależą od specyficznego przypadku. Pierwszym etapem analizy możliwości zastosowania alternatywnych względem gazu ziemnego mediów jest dowiedzenie, że niepewności pomiarów osiągane przy wzorcowaniu gazomierzy tymi gazami odpowiadają w wystarczającym stopniu wzorcowaniu za pomocą gazu ziemnego. Problem ten został już przeanalizowany w różnych opracowaniach, np. [7] i [9], i funkcjonują stanowiska wzorcowania stosujące alternatywne gazy.

\section{Opis stanowiska z pętlą zamkniętą z wykorzystaniem gazu niepalnego}

Użycie do wzorcowania gazomierzy innych gazów niż gaz ziemny jest praktyką powszechnie stosowaną na świecie. Do znanych ośrodków badawczych wykorzystujących alternatywne media w pętlach pomiarowych zamkniętych należą między innymi: Force Technology (Dania), LNELADG (Francja, Poitier), NEL (Szkocja), KRISS (Korea), CEESI (USA, Colorado). Ostatnio na rynku pojawiły się również firmy (Terasen Gas Inc., iMeter B.V., Inotech M.C.S. GmbH) oferujące gotowe stanowiska do wzorcowania gazomierzy z wykorzystaniem ditlenku węgla czy też powietrza lub azotu jako medium. Analizując możliwość wybudowania wysokociśnieniowego stanowiska do wzorcowania gazomierzy, należy rozważyć wiele czynników natury technicznej, ekonomicznej oraz wymogów BHP. Wpływ tych czynników jest w głównej mierze zależny od planowanej dokładności pomiaru, od zastosowanego medium oraz maksymalnego ciśnienia, któremu będzie ono poddane przy maksymalnej wartości przepływu.
Typowy układ z pętlą zamkniętą przedstawiono na rysunku 1.

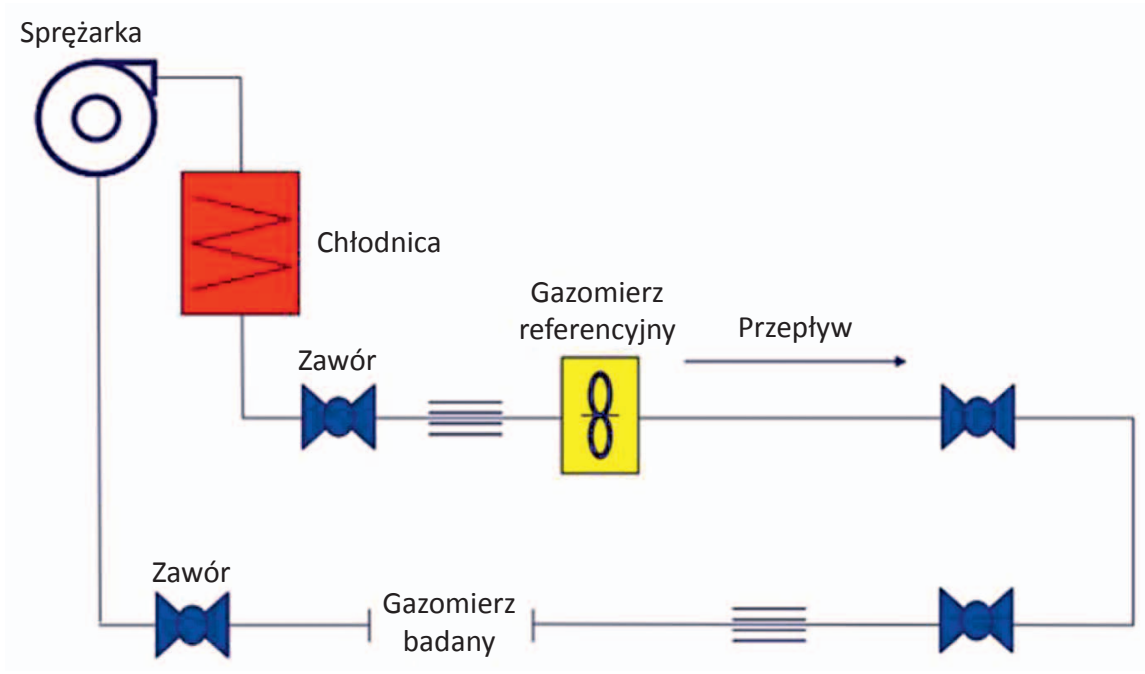

Rys. 1. Schemat typowej instalacji z pętlą zamkniętą do wzorcowania gazomierzy nowiska pomiarowego, które należy odpowiednio zaprojektować i wykonać: 
- gazomierze referencyjne do pomiaru objętości w założonym zakresie strumienia,

- zawory odcinające i armatura przeznaczona na sprężone powietrze,

- układy monitorowania warunków otoczenia oraz warunków pomiarowych,

- filtry i osuszacze powietrza,
- rurociągi wysokociśnieniowe, kołnierze przyłączeniowe, odcinki pomiarowe,

- urządzenia do chłodzenia powietrza,

- układ klimatyzacji pomieszczeń,

- urządzenia przełączające ciągi pomiarowe,

- urządzenia do redukcji hałasu,

- urządzenia przeciwdziałające drganiom i pulsacji.

\section{Wzorce objętości}

Wzorce referencyjne w postaci różnych typów gazomierzy kontrolnych są niezbędne do pomiaru rzeczywistej ilości gazu, która przepłynęła przez badany gazomierz. Można wymienić tu wzorce robocze na stałe zainstalowane w stanowisku oraz wzorce transferowe okresowo wzorcowane w laboratorium odniesienia, które mogą zapewnić powiązanie z europejskim zharmonizowanym metrem sześciennym. Dzięki zwiększonej na przestrzeni ostatnich lat dokładności produ- kowanych gazomierzy możliwe stało się osiąganie niepewności pomiarowych poniżej $0,2 \%$ przez stanowiska wysokociśnieniowe z gazomierzami referencyjnymi. Jest to wartość większa niż w przypadku stanowisk opartych na wzorcach wielkości pierwotnych, gdzie uzyskiwane niepewności pomiarowe podobnego typu badań są poniżej 0,16\%, jednak wzorce wielkości pierwotnych są trudne w budowie i eksploatacji oraz kosztowne w utrzymaniu.

\section{Pomiar ciśnienia i temperatury}

Właściwy pomiar ciśnienia i temperatury jest konieczny do skorygowania wpływu tych parametrów na przepływającą objętość gazu. Do pomiaru temperatury wskazane jest zastosowanie przetworników temperatury z czujnikami $P t$ w klasie dokładności poniżej $0,1 \%\left(<0,05^{\circ} \mathrm{C}\right)$. Czujniki temperatury powinny być umieszczone w tulejach termometrycznych umiejscowionych w odległości $2 \mathrm{D}$ za wylotem gazomierza. Osłona czujnika powinna być umieszczona do głę- bokości 1/3 średnicy rurociągu. Przy wyborze przetworników ciśnienia wskazane jest zastosowanie przetworników klasy $0,05 \%$. Montaż przetworników ciśnienia odbywa się zgodnie z PN-ISO 2186:2010 oraz zaleceniami producenta w taki sposób, aby nie były przenoszone naprężenia mechaniczne na czujnik ani na rurki impulsowe. Rurki impulsowe muszą być tak wykonane, aby nie tworzyły się syfony, zaburzające odczyty ciśnienia.

\section{Armatura}

Zawory odcinające i regulacyjne niezbędne są do sterowania pracą stanowiska. Wymagane jest odpowiednie włączanie lub wyłączanie określonych, wybranych do bieżącego badania gałęzi gazomierzy kontrolnych, zamykanie i otwieranie sekcji gazomierza badanego. Zawory regulacyjne służą do płynnej regulacji strumienia gazu przepływającego przez stanowisko. Niezbędna jest także armatura zabezpieczająca w postaci zaworów upustowych, zamykających, które ze względów bezpieczeństwa mają na celu uniemożliwienie przekroczenia dopuszczalnego ciśnienia w układzie. Zawory powinny posiadać otwory cylindryczne o średnicy rów- nej średnicy nominalnej rury. Aby uniknąć warunków tworzenia się zaburzeń, odcinki rury dopływowej i odpływowej powinny mieć tę samą średnicę. Wszystkie zastosowane zawory muszą mieć wykonanie (klasę ciśnienia) odpowiednie do zakresu ciśnienia roboczego. Układ rurociągów stanowiska obejmuje odcinki pomiarowe gazomierzy kontrolnych i badanych, układ wymienników ciepła i układ wymuszania przepływu za pomocą turbiny. Zaleca się zastosowanie jak najmniej skomplikowanego układu orurowania, w kształcie regularnym, tak aby unikać nadmiernego spadku ciśnienia na instalacji.

\section{Sterowanie pracą stanowiska}

Aby zagwarantować pewną i bezpieczną obsługę stanowiska, niezbędny jest program sterujący automatyczną pracą całego układu. Pozwoli to wyeliminować błędy ludzkie, zarówno w zakresie procedury pomiarowej, jak i rejestracji danych pomiarowych. W procesie pomiarowym wymagana jest jednoczesna rejestracja wielu danych, między innymi ciśnienia, temperatury, warunków otoczenia, impulsów gazomierzy wzorcowych i badanych, 
stałych obliczeniowych. Pomiary z dużą rozdzielczością i częstotliwością wymagają zastosowania oprócz komputera PC również kilku wydajnych i niezawodnych mikrokontrolerów. Każdemu gazomierzowi kontrolnemu i badanemu powinien być przydzielony własny układ mikroprocesorowy mający za zadanie pewne i bezbłędne zliczanie generowanych impulsów. Ponadto należy zapewnić rejestrację takich danych pomiarowych jak: temperatura, ciśnienie i wilgotność względna, zarówno w gazomierzach, jak i w ich otoczeniu, oraz kolejny układ odpowiedzialny za dokładne odmierzanie czasu. Należy umożliwić stabilną i szybką transmisję danych pomiędzy poszczególnymi modułami. Obsługa stanowiska powinna odbywać się z poziomu aplikacji komputerowej.

Zawory otwierające odpowiedni ciąg gazomierza kontrolnego są wyzwalane automatycznie przez system lub mogą być wybrane w trybie ręcznym sterowanym poprzez oprogramowanie. Po osiągnięciu żądanego natężenia przepływu pomiar rozpoczyna się ręcznie lub automatycznie - po uzyskaniu stabilności temperatury w wymaganych granicach.

\section{Utrzymanie warunków termicznych}

Aby zminimalizować oddziaływanie czynników zewnętrznych i różnic temperatury pomiędzy powietrzem w pętli pomiarowej i otoczeniem, należy zapewnić klimatyzację pomieszczeń instalacji. Ponadto wskazana jest taka konfiguracja pętli pomiarowej, aby wszystkie gazomierze referencyjne i badany były na tym samym poziomie wysokości w celu uniknięcia jakichkolwiek wpływów temperatury w instala- cji. Zalecane jest umieszczenie w oddzielnym pomieszczeniu sekcji gazomierzy referencyjnych i badanego lub oddzielenie ich przegrodą, aby utrzymać stabilne warunki temperaturowe bez wpływów z dmuchawy wysokociśnieniowej oraz sekcji wymiennika ciepła. Poprawne zaprojektowanie efektywnego układu chłodzenia, dobranego do zainstalowanych mocy sprężarek, wymaga profesjonalnego projektu.

\section{Zasilanie w sprężone powietrze}

Bardzo istotnym elementem pętli zamkniętej jest układ zapewniający sprężanie gazu i przetłaczanie go w pętli pomiarowej. Na rynku są dostępne sprężarki i dmuchawy wysokociśnieniowe dobrane do przewidzianego zakresu ciśnienia oraz strumienia przepływu. Można określić dwa najbardziej realne rozwiązania:

- wysokociśnieniowa sprężarka śrubowa do sprężania powietrza i jednocześnie wymuszania przepływu,

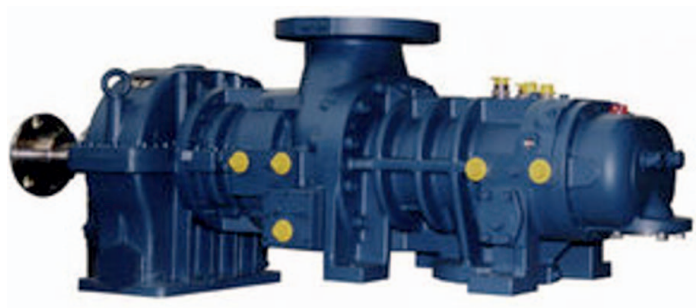

Fot. 1. Sprężarka śrubowa Aerzen typu VR

- sprężarka tłokowa do wytwarzania ciśnienia w instalacji oraz dmuchawa wysokociśnieniowa do wymuszania przepływu - w tym przypadku istnieje również potrzeba zastosowania zbiorników buforowych.

Najbardziej zaawansowane technicznie, ale też najbardziej kosztowne jest zastosowanie sprężarki wysokociśnieniowej, która zapewni sprężanie gazu do wymaganego ciśnienia oraz przepływ gazu w pętli. Będzie to sprężarka dużej mocy. W przybliżeniu można określić, że moc potrzebna do napędu będzie w trzeciej potędze strumienia przepływu. I tak na

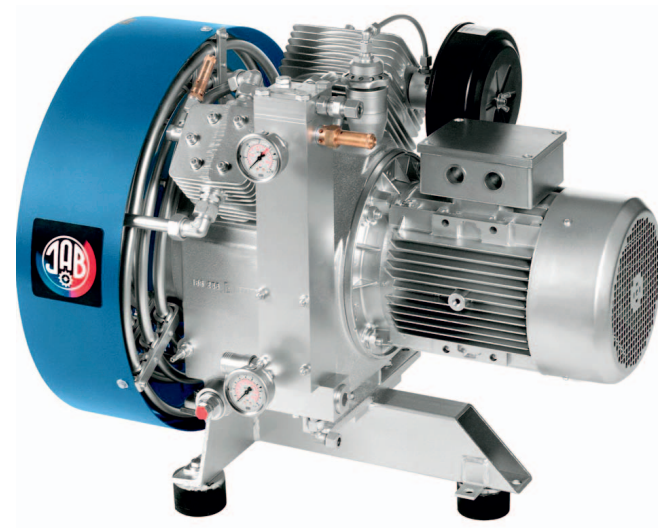

Fot. 2. Sprężarka tłokowa typu SV 600/40

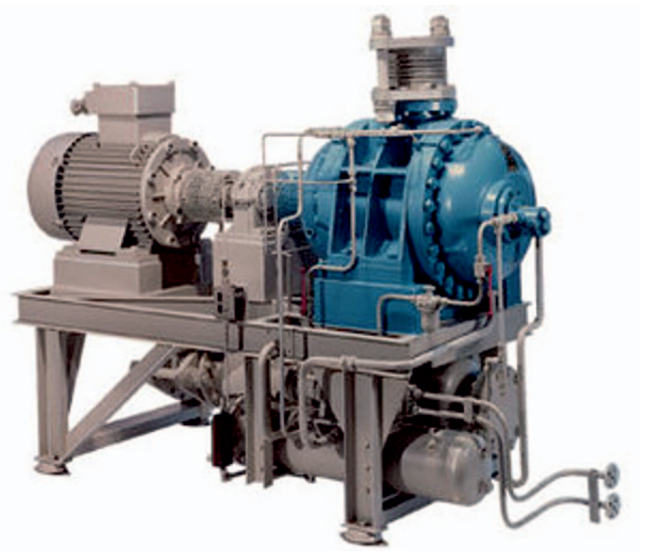

Fot. 3. Dmuchawa wysokociśnieniowa Aerzen PN 25

przykład dla stanowiska z ciśnieniem maksymalnym 50 bar i strumieniem $10000 \mathrm{~m}^{3} / \mathrm{h}$ wymagana jest moc około $300 \mathrm{~kW}$. 
W drugim rozwiązaniu do wytworzenia niezbędnego ciśnienia roboczego w zamkniętej pętli służy sprężarka o niewielkiej wydajności, która zapewnia napełnienie gazem (sprężenie) instalacji w czasie kilku minut. Po napełnieniu instalacji do wytworzenia przepływu gazu będzie wykorzystana dmuchawa, która może pracować pod wysokim ciśnieniem. Rozwiązanie takie może być tańsze niż stosowanie jednej turbiny wysokociśnieniowej. Wydaje się, że najbardziej stabilne warunki zasilania zostaną uzyskane przez zastosowanie sprężarki zasilającej w sprężone, osuszone i przefiltro- wane powietrze zbiornik ciśnieniowy, który pełni rolę bufora i magazynu ciśnienia. Zbiornik zasila pętlę pomiarową, a także sekcję gazomierza badanego poprzez oprogramowanie sterujące do poziomu ciśnienia potrzebnego do przeprowadzenia pomiarów. Zawory otwierające odpowiedni ciąg gazomierza kontrolnego są wyzwalane automatycznie przez system lub mogą być wybrane w trybie ręcznym sterowanym poprzez oprogramowanie. Po otwarciu zaworów zostanie uruchomiona dmuchawa, a bocznik przepływu jest ustawiany wstępnie na zdefiniowane natężenie przepływu.

\section{Podsumowanie}

Kluczem do zapewnienia właściwej dokładności pomiaru jest poprawne wzorcowanie gazomierzy, które uwzględnia rodzaj gazomierza oraz przewidywane ciśnienie robocze. Biorąc pod uwagę bardzo duże ilości gazu przesyłanego w systemie przesyłu, jak również dystrybucji gazu, szczególne znaczenie ma zapewnienie możliwie dokładnego rozliczenia ilości gazu mierzonego na wejściach i wyjściach systemu. Utrzymanie dokładności na właściwym poziomie pozwoli na prawidłowe bilansowanie systemu. Często stanowiska do wzorcowania gazomierzy lokalizowane są na tłoczni gazu, tam gdzie dostępne jest odpowiednio wysokie ciśnienie i przepływ gazu. Rozwiązanie takie jest stosunkowo proste technicznie, niemniej nie umożliwia regulacji temperatury (zależy ona od temperatury w zasilającym rurociągu) oraz zwykle nie daje możliwości regulacji ciśnienia, które zależy od maksymalnego ciśnienia w danej lokalizacji, pory roku czy też sytuacji ruchowej. Naprzeciw temu problemowi wychodzi wzorcowanie w zamkniętych pętlach pomiarowych, które w ostatnich latach stają się atrakcyjną alternatywą z uwagi na możliwość pełnej regulacji ciśnienia, przepływu, jak również kontroli temperatury gazu. Ponadto rozwiązanie to umożliwia zastosowanie w pętli gazów alternatywnych, np. $\mathrm{CO}_{2}$, powietrza, azotu, które jako gazy niepalne nie wymagają szczególnych środków bezpieczeństwa.

Prosimy cytować jako: Nafta-Gaz 2017, nr 5, s. 332-339, DOI: 10.18668/NG.2017.05.05

Artykuł nadesłano do Redakcji 8.12.2016 r. Zatwierdzono do druku 7.03.2017 r.

Artykuł powstał na podstawie pracy statutowej pt. Opracowanie koncepcji stanowiska wysokociśnieniowego do badań gazomierzy przy ciśnieniu roboczym - praca INiG - PIB na zlecenie MNiSW; nr zlecenia: 0057/GM/2016, nr archiwalny: DK-4100-57/16.

\section{Literatura}

[1] Dyakowska E., Jastrzębska R., Stańczak P.: Czy konieczne jest wzorcowanie gazomierzy turbinowych przy przewidywanym ciśnieniu roboczym? Pomiary, Automatyka, Robotyka 1998, nr 1, s. $30-33$.

[2] Gacek Z.: Ocena zgodności gazomierzy turbinowych przeznaczonych do użytkowania w zakresie ciśnień roboczych powyżej 4 barów. Nafta-Gaz 2013, nr 1, s. 78-83.

[3] Gacek Z.: Ocena zgodności przyrzadów pomiarowych na podstawie specyfikacji zharmonizowanych (normy EN i zalecenia OIML) oraz innych dokumentów. Nafta-Gaz 2016, nr 4, s. 262-270; DOI: 10.18668/NG.2016.04.04.

[4] Raczyński A., Witos M., Stasiak J.: Wpływ ciśnienia na zakresowość gazomierzy turbinowych na przykładzie gazomierzy CGT firmy Common. Pomiary, Automatyka, Robotyka 1998, nr 1, s. 9-13.

[5] Richards R., Bertels D.: Test Benches for Calibrating Custody Transfer Gas Meter. Paper for CII New Delhi, February 2007.

[6] Schmiettner D.: Verhalten von Turbinenradgaszaehlern im Hochdruckbereich. GWF-gas/erdgas 1984, vol. 125, Heft 8.

[7] Tang P.W.: Improving Turbine Meter Measurement by Alternate Fluid Calibration. Canadian School of Hydrocarbon Measurement, March 2007.

[8] Tang P.W.: Pressure, Temperature, and Other Effects on Turbine Meter Gas Flow Measurement. American School of Gas Measurement Technology Papers 2015, 16 February 2015.

\section{Akty prawne i normatywne}

[9] A.G.A. Transmission Measurement Committee Report No. 7, Measurement of Natural Gas by Turbine Meters, American Gas Association, Washington, D.C., April 2006.

[10] PN-EN 12261:2005+A1:2008 Gazomierze. Gazomierze turbinowe.

[11] PN-EN 12480:2005+A1:2008 Gazomierze. Gazomierze rotorowe.

[12] Rozporządzenie Ministra Gospodarki z dnia 28 grudnia 2007 r. w sprawie rodzajów przyrządów pomiarowych podlegających prawnej kontroli metrologicznej oraz zakresu tej kontroli (Dz. U. z 2008 r. Nr 3, poz. 13).

[13] Standard Techniczny ST-IGG-0101:2014 Wytyczne wzorcowania gazomierzy przy ciśnieniu $p>4$ bar.

[14] Zalecenia Międzynarodowej Organizacji Metrologii Prawnej OIML R 137 1\&2:2012 Gas Meters.

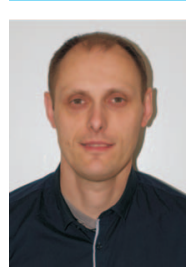

Mgr inż. Paweł KUŁAGA

Główny specjalista inżynieryjno-techniczny; kierownik Zakładu Metrologii Przepływów. Instytut Nafty i Gazu - Państwowy Instytut Badawczy ul. Lubicz 25 A

31-503 Kraków

E-mail: pawel.kulaga@inig.pl 